\title{
Contrastive Analysis of Bilingual and Monolingual EFL Learners' Syntactic Errors in Translation
}

\section{Análisis contrastivo de errores sintácticos en la traducción de estudiantes de inglés como lengua extranjera bilingües y monolingües}

\author{
Ehsan Mohammadi* \\ University of Tehran, Iran \\ ORCID: https://orcid.org/0000-0001-9964-2270 \\ Sina Mohammadi \\ University of Tehran, Iran \\ ORCID: https://orcid.org/0000-0003-0328-6254
}

Received 06-14-20 Revised 08-10-20 Accepted 09-01-20 On line 09-30-20

*Correspondence

Email: Ehsan.mohammadi91@yahoo.com
Cite as:

Mohammadi, H., \& Mohammadi, S. (2020). Contrastive Analysis of Bilingual and Monolingual EFL Learners' Syntactic Errors in Translation. Propósitos y Representaciones, 8 (SPE3), e774. Doi: http://dx.doi.org/10.20511/pyr2020.v8nSPE3.774 


\section{Summary}

This study aimed at the analysis of syntactic errors in translation done by both bilingual and monolingual EFL learners. Research on the subject of the study implied that there might be differences between monolinguals and bilingual learners of foreign languages. The gaps of studies on differences between monolinguals and bilingual's translations from Persian into English language presumed as research question of the study. Through a quantitative and experimental analysis, the researcher collected data from two universities of IAU of South Tehran (monolingual) and Jihad University of Kermanshah (bilingual) using students majoring in translation studies. The OPT test was applied to specify eligible students for the study and then a Persian literary text was offered to students to measure their syntactic errors as introduced by Keshavarz's (1996) model of error analysis. From 100 participants 36 monolinguals and 24 bilinguals were eligible for the study whose translations were scored by the two raters. The results of the study indicated that there is a significant difference between the scores of monolingual and bilingual translators. In addition, the rate of literal errors and approximation was more than other errors that were reported as the result of language learning strategies and communicative strategies. However, new studies are suggested to investigate the types of errors made by monolinguals and bilinguals and graduate students with advanced level of language learning.

Keywords: bilingual, monolingual, translation, literal translation, approximation Resumen

Este estudio tuvo como objetivo el análisis de errores sintácticos en la traducción realizados por estudiantes de inglés como lengua extranjera bilingües y monolingües. La investigación sobre el tema del estudio implicaba que podría haber diferencias entre los estudiantes monolingües y bilingües de idiomas extranjeros. Las lagunas de los estudios sobre las diferencias entre las traducciones monolingües y bilingües del persa al inglés se presume como una cuestión de investigación del estudio. Mediante un análisis cuantitativo y experimental, el investigador recopiló datos de dos universidades de la IAU del sur de Teherán (monolingüe) y la Universidad Jihad de Kermanshah (bilingüe) utilizando estudiantes con especialización en estudios de traducción. Se aplicó la prueba OPT para especificar los estudiantes elegibles para el estudio y luego se ofreció a los estudiantes un texto literario persa para medir sus errores sintácticos tal como lo introdujo el modelo de análisis de errores de Keshavarz (1996). De 100 participantes, 36 monolingües y 24 bilingües fueron elegibles para el estudio cuyas traducciones fueron calificadas por los dos evaluadores. Los resultados del estudio indicaron que existe una diferencia significativa entre los puntajes de los traductores monolingües y bilingües. Además, la tasa de errores literales y aproximación fue mayor que otros errores que se informaron como resultado de estrategias de aprendizaje de idiomas y estrategias comunicativas. Sin embargo, se sugieren nuevos estudios para investigar los tipos de errores cometidos por monolingües y bilingües y estudiantes de posgrado con nivel avanzado de aprendizaje de idiomas..

Palabras clave: bilingüe, monolingüe, traducción, traducción literal, aproximación

\section{Introducción}

Knowing two or three languages is common among people with different ethnicity living in a country, one of these languages is considered as the formal language and based on that language the formal education and teaching is done. It is through language that children come to know the world. If the child's language is different from teaching language the bilingual phenomenon occurs. In this case, the child should learn another language, in addition to her/his native 
language. In this case, they try to learn another language in which needs greater activity, concentration and applying the overall intelligence and IQ to foster another language.

As well, students who are majoring in Learning English language as their second or third language for the purpose of translation may have some errors due to interference of their language grammatical system. Corder (1967) explains the importance of error analysis as and stated that "the study of error is part of investigation of the process of language learning. In this respect, it resembles methological study of acquisition of the mother tongue. It provides us with a picture of linguistic development of a learner and may give us indication as to learning process" (P. 125). In addition, Cenoz (2003) stated that third language acquisition is "the acquisition of a non-native language by learners who have previously acquired or are acquiring two other languages" (p. 71).

Research on differences between monolinguals and bilinguals in acquiring a foreign language was investigated by Pormouzeh and Jahani Azar (2015) and found that there is no significant difference between bilinguals and monolinguals in acquiring language. kasmani and Jangodazi (2014) examined Turkish and Persian EFL students' errors in translation and concluded that "learners of the target language deviate from TL rules, and one can say that interference from their mother tongue is not the core cause of the two groups' errors under the investigation, although there are some differences between the two groups' errors, they are not statistically significant” (p. 36).

This study is a contrastive analysis of syntactic errors made by EFL students of translation studies who are monolingual and bilingual. Monolingual students are Persian speakers learning English as their foreign language in the Islamic Azad University of Tehran South branch and bilinguals are Persian and Kurdish speakers' students in Kermanshah University of Jihad Daneshgahi majoring in English language translation. The problem with bilinguals and monolinguals that are learning the foreign language is that are bilinguals with knowledge of the two grammatical systems have more interference of their languages in learning foreign language, and monolinguals experience less interference due to lack of interfering more language? Or being bilingual may result in rich corpus of language and the process of translation became simple. What is the privilege of bilingualism over monolingual individuals? Having considered the same issue in learning generally and learning foreign language specially, there are many studies that aimed at specifying the nature of the phenomenon.

Due to unclear nature of bilinguals and monolinguals EFL learners' differences the present study emphasized on bilinguals who speak Persian and Kurdish (Kalhori) and those who only speak Persian language. The interference of Kalhori Kurdish was examined and differences between the two groups was investigated in their translations from Persian into English. Accordingly, the following research questions were investigated:

1. Is there any significant difference between monolingual and bilingual in their syntactic errors of translations?

\section{Literature Review}

Despite great interest in how the bilingual brain houses two languages and the extent to which bilinguals' two linguistic systems may be fused or differentiated in one brain, existing brain research is equivocal. Classic neuropsychological studies of bilingual aphasics have shown that individuals may selectively lose only one language and not the other, thereby supporting a language differentiation view (Paradis, 1977).

The scarcity of direct comparisons of bilingual versus monolingual brains during language processing tasks - and the need for tasks involving more complete levels of language competence (e.g., morphological and syntactic)-leaves unanswered questions about the 
similarities and differences between monolingual and bilingual brains. First, it is still equivocal as to whether bilinguals recruit the same classic language areas in the same manner, for the same functions of language processing, and with the same location and extent as monolinguals-including the superior temporal gyrus which is known to be important in phonological processing (Zatorre \& Belin, 2001; Petitto et al., 2000). Second, the anatomical studies noted above suggest that there are structural changes in a person's brain as a result of extensive bilingual exposure, including enlargement of brain areas such as the inferior parietal cortex (Mechelli et al., 2004). Thus, another important question is whether such purported structural changes in the brains of bilinguals also result in differences between bilingual versus monolingual language processing. Only a direct comparison between bilinguals and monolinguals, using neuroimaging and behavioral paradigms, would ideally address these issues.

Yuko et al (2006) in "Bilingualism and Second Language Acquisition" studied bilingualism and second language acquisition and indicated that first language impacts of learning second language and represented that each bilingual individual will develop a unique linguistic, cognitive, and socio-cultural profile that is distinct from that of monolingual individuals.

Ioulia Kovelman et al (2009) in a study found that behaviorally, in English, bilinguals and monolinguals had the same speed and accuracy, yet, as predicted from the Spanish-English structural differences, bilinguals had a different pattern of performance in Spanish. One study indicated that "strategies used by monolingual and bi/multilingual learners showed that multilingual learners are more flexible in using different strategies in comparison with monolingual learners" (Moghadam, Ghanizadeh and Akbari, 2015, p. 237). But studies by Pormouzeh and Jahani Azar (2015) and study of Bagherzadeh Kasmani and Jangodazi (2014) indicated that there are no significant differences between the two groups. Yasin Khoshal (2017) studied translation errors of elementary EFL learners and stated that "correct use of articles should more often be the focus for EFL context, and the use of correct verbs and tenses should also be absolutely clarified and emphasized" (p. 89). Otherwise, Keshavarz (1996) provided the effect of interference, fossilization and interlanguage...on making syntactic errors and emphasized the effect of complex systems of languages on errors.

Regarding the significance of errors Keshavarz (1996) wrote, "many scholars in the field of error analysis have stressed the significance of second language learners errors. As cited in Corder, (1967), for instance, in his influential article, remarked that..."they are significant in three different ways. First to the teacher, in that they tell him, if he undertakes asystematic analysis, how far towards the goal the learner has progressed and, consequently, what remains for him to learn. Second, they provide to the researcher evidence of how language is learned or acquired, what strategies or procedures the learner is employing in his discovery of the language. Thirdly, they are indispensable to the learner himself, because we can regard the making of errors as advice the learner uses in order to learn. It is a way the learner has for testing his hypotheses about the nature of the language he is learning" (p. 44-45).

\section{Method}

This study was performed to contrast bilinguals and monolinguals EFL learners' syntactic errors in their translations. The English structure as the correct syntactic criteria will be tested in the present study to discover whether bilinguals commit more errors or monolinguals in their translations. To compare the Persian and Kurdish languages, the syntactic structure of the two languages was studied and interferences and fossilization in terms of Keshavarz (1996) was examined. To do the study 100 students mainly BA students in Teaching English language were selected for the study from the two Universities from different provinces. Bilinguals were selected from Jihad university of Kermanshah and monolinguals were selected from Islamic Azad University of Tehran South Branch. The population of this study is 100 students of 
Islamic Azad University of Tehran South branch in translation studies and students of Jihad University of Kermanshah. Scores were considered from 0 to 20 since the scores. Out of the entire students, eligible ones were selected for the analysis including student from 18 to 27 years old who were in the intermediate level of language proficiency using Oxford Placement Test. The text that is selected for translation is selected from Sadegh Hedayat's The Blind Owle. The study is a quantitative research usinglibrary resources and experimental study. The first research question is quantitative and other questions are qualitative. This model was derived from Keshavarz's approach (1996) regarding contrastive error analysis.

The model consists of four stages including:

(1) interlingual errors,

A. Transfer Error: error caused by interference from mother tongue. A student who has not known the rules of target language will use the same rules as he obtained in his native language.

B. Mother tongue Interference: errors are produced in the learners' attempt to

discover the structure of the target language rather than transferring models of their first language.

C. Literal Translation: errors happen because a student translates his first language sentence or idiomatic expression in to the target language word by word.

(2) Interalingual and developmental errors,

A. Overgeneralization: it happens when a learner creates a deviant structure on the basis of his experience of other structure in the target language. Littlewood (1984) cites the example of forming plural by adding "s" to even irregular plurals, also generalizing the "-ed" past form.

B. Ignorance of Rule Restrictions: ignorance is specific in the sense that one is normally said to be ignorant of structure; the learner of the second language does not obey the structure of the target language. In this type of error, the learner fails to observe the restrictions of existing structures. Some rule restriction errors may be accounted for in terms of analogy and may result from the role learning of rules.

C. Incomplete Application of the Rules: this error may occur when learner fails to apply the rules completely due to the stimulus sentence.

D. False Concept Hypothesized: learners' faulty understanding of distinctions of target language items leads to false conceptualization. Learners' faulty understanding of distinctions of target language items leads to false concept hypothesized.

(3) transfer of training

A. Transfer of Phonological Elements

B. Transfer of Morphological Elements

C. Transfer of Grammatical Elements

(4) language learning strategies and communicative strategies."

A. Avoidance: 1 . Topic avoidance (The learner simply tries not to talk about concepts for which the TL item or structure is not known), 2. Message abandonment (The learner begins to talk about a concept but is unable to continue and stops in mid- utterance.)

B. Paraphrase: 1. Approximation (Use of a single target language vocabulary item or structure, which the learner knows is not correct, but which shares enough semantic features in common with the desired item to satisfy the speaker (e.g., pipe for waterpipie) 2. Word coinage (The learner makes up a new word in order to communicate a desired concept (e.g., airball for balloon) 3. Circumlocution (The learner describes the characteristics or elements of the object or action instead of using appropriate TL item or structure ("she is, uh, smoking something. I don't know what's its name. That's, uh, Persian, and we use in Turkey, a lot of.")

C. Conscious transfer or borrowing. 1. Literal translation (The learner translates word for word from the native language ("He invites him to drink," for" They toast one another.") 2. Language switch (The learner uses the native language term without bothering to translate (e.g., balon for balloon) 3. Appeal for assistance (The learner asks for the correct term ("what is this? What called?") 4. Mime (The learner uses nonverbal strategies in place of a lexical item or action (e.g., clapping one's hand to illustrate applause). 


\section{Results}

Table 1.

Descriptive statistics of Oxford Placement Test

\begin{tabular}{cccccccc}
\hline \multicolumn{7}{c}{ Descriptive Statistics } \\
\hline & $\mathrm{N}$ & Minimu & Maximu & Sum & Mean & $\begin{array}{c}\text { Std. } \\
\text { Deviation }\end{array}$ & Variance \\
OPT & 60 & 36.00 & 82.00 & 3551.90 & 59.1983 & 9.94416 & 98.886 \\
Valid N & 60 & & & & & & \\
\hline
\end{tabular}

The following diagram is the humanizing result of students test. The curve represents homogenized distribution of scores of OPT test.

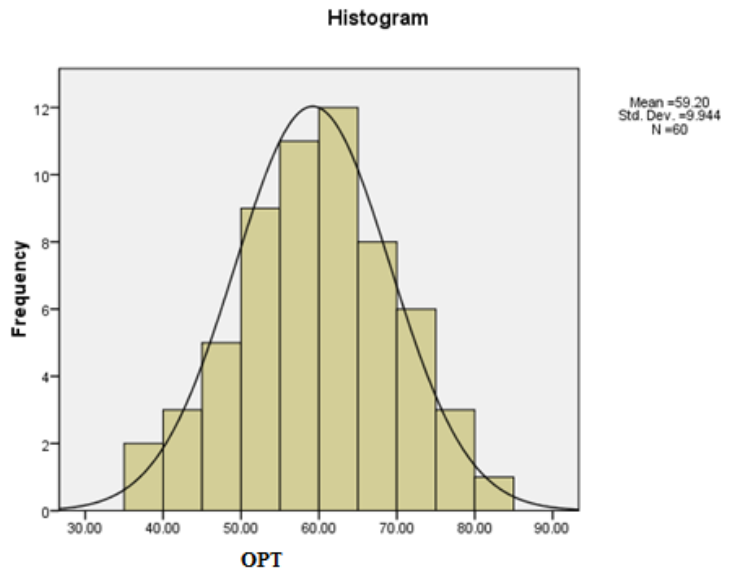

Table 2.

Figure 1 Result of homogenizing test

One sample t-test of the PET

One-Sample Test

Test Value $=0$

$\mathrm{t}$

df

Sig.

(2- Mean

95\% Confidence Interval

tailed)

Difference

of the Difference

Lower

Upper

$\begin{array}{lllllll}\text { pet } & 46.112 & 59 & .000 & 59.19833 & 56.6295 & 61.7672\end{array}$

The above table shows that the t-value is 46.11 and $\mathrm{df}$ is 59 .according to the table the sig level is less than 0.05 which represents the significant homogeny and normality of data. Accordingly, the lower and upper interval difference is 56.62 and 61.76 respectively.

Comparison of translations by bilinguals vs. monolinguals

In order to compare the mean scores of bilingual and monolingual groups the independent samples test was used to compare the results of the two groups. Group statistics shows that the 
mean of bilingual group is more than monolingual group and it is less than one score. It shows that the bilingual groups translation scores is more than monolingual group.

Table 3.

Group statistics for monolinguals and bilinguals

\begin{tabular}{llllll}
\hline Group Statistics & & & & & \\
\hline Groups & $\mathrm{N}$ & Mean & Std. Deviation & $\begin{array}{l}\text { Std. } \\
\text { Mean }\end{array}$ & Error \\
monolingual & 20 & $\begin{array}{l}16.750 \\
0\end{array}$ & 1.06992 & .23924 & \\
$\begin{array}{l}\text { Group } \\
\text { bilingual Group }\end{array}$ & 20 & $\begin{array}{l}17.700 \\
0\end{array}$ & 1.21828 & .27242 & \\
\hline
\end{tabular}

H1: Is there any significant difference between monolingual and bilingual in their syntactic errors of translations?

$\mathrm{H} 0$ : There is not any significant difference between monolingual and bilingual in their syntactic errors of translations.

In the following table, the level significance for comparing the mean of the two groups is 0.013 that is less than 0.05 , therefore, with $95 \%$ confident we can say that $\mathrm{H} 0$ indicating "there is not any significant difference between monolingual and bilingual in their syntactic errors of translations" is rejected. In other words, there is a significant difference between results of the two groups in case of syntactic errors of their translations.

Table 4.

Independent sample test for comparing the result of the two groups

\begin{tabular}{|c|c|c|c|c|c|c|c|c|}
\hline \multicolumn{9}{|c|}{ Independent Samples Test } \\
\hline \multirow{8}{*}{$\begin{array}{l}\text { Equal } \\
\text { variances } \\
\text { assumed }\end{array}$} & & \multicolumn{7}{|c|}{ t-test for Equality of Means } \\
\hline & & \multirow[t]{4}{*}{$\mathrm{t}$} & \multirow[t]{4}{*}{ df } & \multirow{4}{*}{$\begin{array}{l}\text { Sig. (2- } \\
\text { tailed) }\end{array}$} & \multirow{4}{*}{$\begin{array}{l}\text { Mean } \\
\text { Difference }\end{array}$} & \multirow{4}{*}{$\begin{array}{l}\text { Std. } \\
\text { Error } \\
\text { Differ } \\
\text { ence }\end{array}$} & \multicolumn{2}{|c|}{$95 \%$ Confidence } \\
\hline & & & & & & & \multirow{2}{*}{\multicolumn{2}{|c|}{$\begin{array}{l}\text { Interval of the } \\
\text { Difference }\end{array}$}} \\
\hline & & & & & & & & \\
\hline & & & & & & & Lower & Upper \\
\hline & & - & 38 & .013 & -.95000 & .3625 & -1.68396 & \\
\hline & & 2.620 & & & & 6 & & .2160 \\
\hline & & & & & & & & 4 \\
\hline Equal & & - & 37.3 & .013 & -.95000 & .3625 & -1.68436 & - \\
\hline variances & not & 2.620 & 77 & & & 6 & & .2156 \\
\hline assumed & & & & & & & & 4 \\
\hline
\end{tabular}

frequent types of errors are summarized in the following table. It shows that the most frequent errors of translations belongs to the category of "language learning strategies and communicative strategies" (30\%) such as approximation and literal translation. Then false application of rules of language (23\%) that is a parameter for "interalingual and developmental errors" was frequent. The other category that is frequently used is "transfer of training" that was shown in transfer of phonological and morphological elements and dictation errors. Finally, "interlingual errors" $(20 \%)$ were reported as the most frequent errors in students translations in general. 


\section{Table 5}

Types or errors and subcategory of errors

\begin{tabular}{|c|c|c|c|}
\hline Types of errors & Subcategories of errors & Subcategories of errors & $\begin{array}{l}\text { Scores for each } \\
\text { type of error }\end{array}$ \\
\hline interlingual errors & Transfer Error: & & $20 \%$ \\
\hline & $\begin{array}{l}\text { Mother tongue Interference: } \\
\text { Literal Translation: }\end{array}$ & & \\
\hline Interalingual and & Overgeneralization: & & $23 \%$ \\
\hline developmental & Ignorance of Rule Restrictions: & & \\
\hline & $\begin{array}{l}\text { Incomplete Application of the } \\
\text { Rules: } \\
\text { False Concept Hypothesized: }\end{array}$ & & \\
\hline transfer of train- & Transfer of Phonological Elements & & $22 \%$ \\
\hline & $\begin{array}{l}\text { Transfer of Morphological Ele- } \\
\text { ments } \\
\text { Transfer of Grammatical Elements }\end{array}$ & & \\
\hline $\begin{array}{l}\text { language learning } \\
\text { strategies and } \\
\text { communicative } \\
\text { strategies }\end{array}$ & $\begin{array}{l}\text { Avoidance } \\
\text { Paraphrase: } \\
\text { Conscious transfer or borrowing }\end{array}$ & $\begin{array}{l}\text { Topic avoidance } \\
\text { Message abandonment } \\
\text { Approximation } \\
\text { Word coinage } \\
\text { Circumlocution } \\
\text { Literal translation } \\
\text { Language switch } \\
\text { Appeal for assistance } \\
\text { Mime }\end{array}$ & $30 \%$ \\
\hline
\end{tabular}

\section{Discussion}

The results of the study indicated that there is a significant difference between scores of translations done by bilinguals and monolinguals. In effect, bilinguals outperformed monolinguals in their translations since they had less syntactic errors. It seems that bilinguals are more conscious of grammatical and syntactic differences between languages. Therefore, they can acquire the foreign language based on the logical construction behind its linguistic and syntactic system. Since previous studies took into account neurological mechanism of bilinguals as a determining agent in prevalence of bilinguals, the present study supports this idea. In case of translation errors as general result of students errors were specified it was revealed that literal translations and errors related to language learning strategies and communicative strategies are the most frequent errors. Accordingly, it is hopeful that through education of translation strategies learners develop their language proficiency and translation strategies.

In congruent with the results of present study is the study by Kovelman et al (2009) who believed bilinguals and monolinguals had the same speed and accuracy, but as predicted from the Spanish-English structural differences, bilinguals had a different pattern of performance in Spanish. In addition, it is believed that multilingual learners are more flexible in using different strategies in comparison with monolingual learners" (Moghadam, Ghanizadeh and Akbari, 2015, p. 237). The study by Khoshdel (2017) emphasized the errors of elementary EFL learners errors in translations mostly in the usage of verbs and articles that refers to 
syntactic errors in translation. However, other studies such as that of Pormouzeh and Jahani Azar (2015) and Bagherzadeh Kasmani and Jangodazi (2014) indicated that there are no significant differences between the two groups.

\section{Conclusion}

The present study aimed at comparison of monolinguals and bilinguals errors in translation of Persian texts into English. Accordingly, through Keshavarz (1996) model of error analysis, students errors were specified and categorized in general and differences between scores of the bilinguals and monolinguals were specified. Results indicated that there is a significant difference between scores of bilinguals and monolinguals so that bilingual translators outperformed monolinguals. All students' errors were nearly in the same range but students' scores showed a significant difference. However, the types of errors made by students were mostly errors that are the result of language learning strategies and communicative strategies; therefore, it is difficult to classify the types of errors made by each group of learners. Besides other extensive studies are required to measure types of errors made by bilinguals and monolinguals to specify which error is specific to monolingual or bilingual translators.

\section{Referencias}

Cenoz, J. (2003). The additive effect of bilingualism on third language acquisition: A review. International Journal of Bilingualism, 7(1), 71-87.

Corder, S. P. (1967). The significance of learner's errors. IRAL-International Review of Applied Linguistics in Language Teaching, 5(1-4), 161-170.

Kasmani, M. B., \& Jangodazi, K. (2014). An Analysis of Errors Made by Turkish and Persian Speaking EFL Students Majoring in Translation. Asian Journal of Management Sciences \& Education, 3(2), 36-41.

Keshavarz, M. H. (1996). Contrastive analysis \& error analysis. Rahnama Press, 1000 ..

Khoshhal, Y. (2017). An Error Analysis Case Study: Out of Context Translation of Persian Sentences into English for Elementary EFL Learners. Educational Process: International Journal (EDUPIJ), 6(4), 89-100.

Kovelman, I., Shalinsky, M. H., White, K. S., Schmitt, S. N., Berens, M. S., Paymer, N., \& Petitto, L. A. (2009). Dual language use in sign-speech bimodal bilinguals: fNIRS brain-imaging evidence. Brain and language, 109(2-3), 112-123.

Mechelli, A., Crinion, J. T., Noppeney, U., O'Doherty, J., Ashburner, J., Frackowiak, R. S., \& Price, C. J. (2004). Structural plasticity in the bilingual brain. Nature, 431(7010), 757-757.

Moghadam, S. B., Ghanizadeh, A., \& Akbari, O. (2015). The Effect of Bilingualism on the Listening Strategies and Listening Anxiety among Iranian Junior High School Students. Journal of Applied Linguistics and Language Research, 2(4), 236-248.

Paradis, M. (1977). Bilingualism and aphasia. In Studies in neurolinguistics (pp. 65121). Academic Press.

Maghsoudi, T., Davodi, H., \& Hekmat, M. (2013). Agricultural production cooperatives, entrepreneurship and education in Iran. African Journal of Business Management, 7(18), 1806-1813.

Petitto, L. A., Katerelos, M., Levy, B. G., Gauna, K., Tétreault, K., \& Ferraro, V. (2001). Bilingual signed and spoken language acquisition from birth: Implications for the mechanisms underlying early bilingual language acquisition. Journal of child language, 28(2), 453-496. 
Petitto, L. A., Zatorre, R. J., Gauna, K., Nikelski, E. J., Dostie, D., \& Evans, A. C. (2000). Speech-like cerebral activity in profoundly deaf people processing signed languages: implications for the neural basis of human language. Proceedings of the National Academy of Sciences, 97(25), 13961-13966.

Pormouzeh, A., \& Azar, L. J. (2015). Investigating the Effect of Bilingualism and Social Class on Class Participation of Iranian EFL Learners. Procedia-Social and Behavioral Sciences, 192, 290-297.

Butler, Y. G., \& Hakuta, K. (2004). Bilingualism and second language acquisition. The handbook of bilingualism, 114-144.

Maghsoudi, T., Hekmat, M., \& Davodi, H. (2012). Supporting the entrepreneurship development in the agriculture production cooperatives. African journal of Business management, 6(10), 3639-3647.

Zatorre, R. J., \& Belin, P. (2001). Spectral and temporal processing in human auditory cortex. Cerebral cortex, 11(10), 946-953. 